\title{
Research Literature Review on Western Feminist Literary Criticism
}

\author{
Tingting Zhang
}

Teaching and Research Institute of Foreign Languages, Bohai University, Jinzhou, 121013, China

tingting810905@163.com

Keywords: western feminist literary criticism; research literature review; development stage; basic theory; main classification

\begin{abstract}
Feminist literary criticism as a criticism schools, is marked by gender, widespread gender awareness and female consciousness is its fundamental characteristics. Western feminist literary criticism after decades of development, and achieved gratifying costs. The main content of this paper is divided into three aspects, the development stage, basic theory and main classification on western feminist literary criticism. Among them, the development stage summarized into three stages according to the characteristics; the basic theory mainly researches "female writing" theory from Helene Cixous and "female criticism" theory from Elaine Showalter; the main classification divided into five categories according to the research orientation. Through in-depth studies the literature related western feminist literary criticism and provides foundation for Chinese female literary criticism and writing research.
\end{abstract}

\section{Introduction}

Female literature refers to the consciousness having female gender and creation using the language and culture of women, the contents of performance related with the unique experience of female life and feel, the text shows the works of female discourse unique quality and life force [1]. Feminist literary criticism is larger than any other criticism theory on literature standards, is one of the richest spirit of innovation strength in modern critical theory. Western feminist literary criticism from the late 1960s to the mid-1970s focused on exposing that the male culture distorted image of women; from the mid 1970s to the mid-1980s, focused on interpretation of the classic works from the perspective of feminist; after the mid-1980s access to interdisciplinary cultural research, deep into the study of "gender poetics". Feminist literature is based on feminist politics literature, is the literature oriented for the feminist movement and based on the experience of women as expression objects, and is a distinctive vanguard literature.

Vision of women literature is open and development system, rather than a closed and static, is based on gender consciousness for authoress, gender perspective to the attention of the female destiny, women emotion, the literature of life, or gender-based super-consciousness, super gender perspective performance, including women survival and the text of universal human significance. Female literature is still to be explored and a perfect proposition. Female literary fully express the unique feminine charm and strange ideas, and improve the essence of humanity itself, to show the various stages of female roles that, dig out the deepest soul monologue. You can clearly feel those cries, those anxious, those frivolous, those strong, experience with women's unique concept of faith. Chinese female literature is born in a certain social and historical conditions, "May Fourth" New Culture Movement as the beginning of modern human connotation, female-body experience, thinking subject, the aesthetic subject and body of literary speech. Chinese female literature and the "May Fourth Movement" and the birth of a new culture at the same time experienced nearly a hundred years of historical vicissitudes, emerged five or six generations of women writers and a wealth of creative performance. In the 21st century, it is undoubtedly the Chinese and Western cultures collide and confront period, especially now after the Cold War, the Western culture to the aggressive trend disdain Oriental culture camp. In order not to become the next century cultural and academic losers, should take the initiative to start a dialogue with the Western culture, in the dialogue mutual Complementary to achieve intercultural creation and construction. 


\section{Development Stage on Western Feminist Literary Criticism}

Women worldwide literature, appears in the modern industrial revolution and the democratic revolution, and after the Reformation agricultural society to modern industrial and commercial society during the transition process occurs in modern popular in modern human thought. Country-specific time varies, generally in the 19-20 century literature together into a worldwide trend. Especially in the latter half of this century, Western women in the fight for human rights and the feminist movement, driven by the female literature throughout the developed and underdeveloped regions of the world. In 17th and 18th century, although French is known as the "Women's Time", women are few writers before the 20th century. Even in the cradle of the Renaissance in Italy and Greece, but also the emergence of a large number of women writers of the 19th century and early 20th century. Thus, 19-20 century is the century of female literature, literature gorgeous sunrise in women worldwide. As feminist women's movement in extending the academic field, the Western feminist literary criticism has gone through three stages of development [2]:

The first phase (late 1960s to mid-1970s), the main attack male sexism, centralized literature reveals distorted and demeaning to women, critical literature "misogyny", criticized the traditional "penis criticism. " Kate Millett's "Sexual Politics, 1969", is an important book mark the official birth of feminist criticism, from the difference between men and women, focusing on exposing the male-centered literature distorting the image of women, critique patriarchal society. The author believes that sex is such a deep-rooted political domination; it is difficult to completely clear. Historically, most patriarchal society by way of legislation have strengthened the male to female control and domination; Mary Ellmann's "Thinking About Women, 1968", the image of men from women and men critic Writers Works women works, summed nine female models: invisible, passive, instability, closed, chastity, materiality, spirituality, irrational, compliance. The book is a critique of the male female twist on the image of women work in the liquidation of important works, is one of the important literary problem of research in this area; Germaine Greer's "Female Eunuch, 1970", author dauntless spirit of criticism, In sharp thinking and profound knowledge, to the patriarchal society and traditional thinking war, he noted women imprisoned in spiritual captivity moment, gradually lost its vitality, thus become "castrated person", namely "The Female Eunuch . " This class requires women to rise up against her, "Woman is a class, and is the most oppressed class" concept, is an important element of radical feminism to grow later.

The second phase (mid-1970s to mid-1980s), focusing on the works of women writers is extremely retroactive women writers own literary tradition, large-scale re-excavated women's literature and reading various countries and periods, the interpretation of the classic works of invoking feminist perspective, focused in language and literature criticism. This stage feminists found belong to their own literary works, many women writers and their works have been re-examining and concerns of women on a large number of theoretical research and published. Ellen Moer's "Literary Women, 1976", the first description of female literary history, one by one analysis of the 18-20 century Britain, the United States, France's well-known women writers, they are regarded as the pioneer of full vitality. Starting with one study on women writers from the traditional women's, laid the "Women's Center criticism" basis. Elaine Showalter's "A Literature of Their Own, 1977", overlooking the female literary writing nearly two hundred years of the development process, not just a comb female literature development history of literature, also hidden behind women seeking self-development Independent seeking freedom struggle. Female authors writing history is divided into three stages, namely "Feminie, Feminist, and Female", respectively imitation stage, stage protests and self-discovery phase. On the female writing into historical and cultural context of a longitudinal development to explore, he pointed out the characteristics and difficulties women face female writers writing; black feminist literary criticism, lesbian literary criticism at this stage are gradually development and growth, the French feminist criticism began to spread in Britain and America, began the feminist criticism Diversified period.

The third stage (mid-1980s). Feminist Thought and Postmodernism began to have more frequent exchanges, more feminist research and accepted the ideas and methods of deconstruction, the 
emergence of so-called "post-modern feminism schools". This phase reflect the basic concepts of literary studies fundamentally revise based theory of reading and writing of men experience assumptions. Development of an interdisciplinary, cross-gender feminist culture, no longer stick to literature itself, the rise of a comparative study of gender differences "gender poetics", showing a diverse theoretical pattern. Gender is a basic reality existed in human society, for the cultural production have the potential restraining effect. "Gender Poetics" from the relationship between gender and culture of start-depth study of the impact of culture and of literature, especially for women in the literature on the unique role of giving a great deal of attention. Julia Kristeva's "Woman's time", discusses the relevance of feminism and femininity and the symbolic order of. Female body is not only dependent on the cyclical time also belong to monumental time, these two kinds of time-dimension is the identity of the mother under the perspective of production and reproduction. Research hopes a new feminism; motherhood can be maternal time and linear time to coordinate. Its position is that only take into account the desire of women continue to want to have children in order to prevent the feminist struggle Inability to religion and mysticism go.

\section{Basic Theory on Western Feminist Literary Criticism}

In certain areas of activity theory with actual deduced concept or principle, or a simplified description of things through long-term observation of things and summary extraction of a thing in the process of the formation of the key factors in the evolution of the model . The basic theory of the western feminist literary criticism has a lot, but fragmentation, fragmentation [3,4]. The following two theories have representative:

(1) Helene Cixous and "female writing" theory. Helene Cixous is a novelist, dramatist and literary theorist, one of the most influential contemporary France. In France and Britain and other countries, many experiments she is known for creation and vanguard theory. Cixous is a unique writer and theorist; she was in an entirely new way to express their thoughts and feelings. Whether novels or in the theoretical writings, and she is good at combining the wording in the discussion and lyrical language vivid, poetic and imagery, there is a lot of anti-rational color. Helene Cixous believes that in patriarchal society, men and women of binary oppositions positive values mean that men are representative of women in the binary oppositions are being excluded from the patriarchal center of the "otherness" can only serve as proof of the existence of men and the value of tools and symbols. To remove stubborn binary opposition and overthrow patriarchal repression, it is necessary from the language of deconstruction and critique from writing begins. Women must put their written article, like embedded world and history as through their own struggle. Helene Cixous try to make writing a revolutionary, she presented "female writing" promote the female subconscious revolutionary forces and all-embracing maternal characteristics, an attempt to break the binary opposition mode, exploration and enthusiasm in the political theory of We are valuable. However, she gave the woman writing gives too heavy mission. Language, after all, just the language, but not self-sufficient existence, can influence all the power.

(2) Elaine Showalter and the "feminist criticism" theory [5]. Elaine Showalter is one of the founders of American feminist criticism. Her career and career success almost simultaneous development of the American feminist, maximum contribution and theory into American feminist criticism is to tap the female literary tradition, women's literature to build buildings, the creation of "Women Criticism" encouraging female culture. Although her theory is constantly attacked from the French school, but still has an important position in American academia. Elaine Showalter to the feminist research into two modes, one is the women as male consumers, study of male texts images of women, the study of literature and criticism ignores history and demeaning to women writers, as well as female audience passive position explore literary ideology; the other is a female language problems, literature and the history of women writers in particular article women power producers as text writing, research writing of women. Elaine Showalter stressed that women should not rely solely on criticism of the theory of male masters, not only to the male master theory correction, diversion, subversion and rebellion, but must establish their own theories. "women criticism" theory mainly includes two aspects, one woman reading from an agreed-type reader type reader into a 
revolt, rooted in the hearts of women to get rid of male consciousness; the second is the creation of women, female writing is the basis the process of forming the subject of female characteristics and female experience to build female literary writing language system has become an important task in the new era of feminist critics.

\section{Main Classification on Western Feminist Literary Criticism}

Western feminist literary criticism is mainly divided into the following five categories [6, 7]:

(1) The Marxist feminist literary criticism [8]. Based on the classic Marxist "economic base superstructure" theory to explain women's issues. The literature as an important way to achieve the target of feminist culture, if there is no common political basis; there can be no possible recognition of feminist criticism. Feminist criticism is a political act; its goal is not just to explain the world, but also to change the world by changing the relationship between the reader and the reader's consciousness and works between. Development of Marxism actuation propulsion feminist theory, feminist also provided resources to Marxism.

(2) Psychoanalytic feminist literary criticism [9]. Psychoanalysis is developed in clinical practice for neurosis set theory and technology. Psychoanalysis and unconscious mental activity are more concerned about the level of gender awareness and its profound impact on the literary activity. Many feminists believe that psychoanalysis can be a powerful tool for literary criticism. In recent years, critics have been considering the possibility of establishing new female psychoanalysis; Freud's theory is not a patch, but stressed gender identity development and construction.

(3) Eco-feminist literary criticism [10]. Eco-feminism western feminist movement and ecological movement with the product, emphasizing the intrinsic link between women and nature, explore and compare for women and demeaning nature of the special relationship between the two phenomena, aimed at establishing equality gender relations and harmonious relationship between man and nature. Eco-feminist literary criticism exploration and exploitation of natural inherent oppression of women associate these two phenomena, the spearhead of criticism from patriarchal culture concept up to anthropocentrism, questioned and criticized both hidden behind two ideologies opposition system.

(4) The post-modern feminist literary criticism [11]. Postmodern Feminist literary criticism is postmodernism and feminist literary criticism at specific historical stage of integration can be used to effectively criticize problematic feminism, after the formation of such a multi-modern feminism feminist perspective, and after the creation of this guide and criticism of modernism text. Postmodernism is headed west to the common law of feminist literary criticism development, after the feature has Postmodernist text modern woman abandoned Enlightenment values and modern rationality, for feminism has important significance, is an important weapon in the fight against feminism.

(5) Post-colonial feminist literary criticism [12]. Postcolonial feminist theory was born in the context of multiple oppressions and multiple resistances among the issues discussed are beyond gender, race and other re-examine the state and the question of class relations. The main task facing this theory is how to adjust the nationalism and feminism. Postcolonial feminist cultural criticism practice will be mainly female writers as the research object, the performance of groups of women from different angles edge in the multiple oppressions of pain as well as the underlying rights of women, to help them make their voices heard and to seek resistance strategies. 


\section{Conclusion}

The mission of feminist literary criticism is to re-read the classic texts of human, analyze the male culture mentality reflected by feminist image in the male female writers; study the nature and characteristics of female writing, rebuild the subject of female writing and find the character of female literature; seek and establish female literary tradition, women writing rewrite history, to provide experience for overcoming women writing difficulties [13]. Feminist literary criticism in the New China, on the basis of accepting criticism theory from western feminist, inherited the poetic tradition in Chinese classical literary criticism, constructed China's feminism literary criticism, make Chinese feminist literary criticism focus on women's social status and role, and also do not give up literary research for feminist literary and the attention of culture, which is the persistent pursuit of Chinese feminist literary criticism. But the theory, words and method of China's feminist literary criticism in the research process basically follows the western developed countries, and sometimes even overall copy, basically "ism", and lack of local theoretical construction. Through in-depth studies the literature related western feminist literary criticism and provides foundation for Chinese female literary criticism and writing research.

\section{Acknowledgement}

This work is supported by social science fund project of Liaoning province (L15CWW001): Western Feminist Literary Criticism and Its Influence on Chinese Female Writing.

\section{References}

[1] Y. Ma, "Feminist literary criticism in foreign literature works," Journal of Jiamusi College of Education, vol. 31, no. 5, pp. 85-86, 2014.

[2] G. Y . Guan, "Context and translation in the context of relevant context theory," Overseas English, vol. 16, no. 2, pp. 3-4, 2015.

[21] Baidu library, "Feminist theory and feminist writing," http://wenku.baidu.com/link?url=xOS9LmVjD6ljg7eS08EZGbww_iTzA3i6PmF9sruG2HUu_ LNpyjRIajyvixqtbQxNjZhc1BbKaH3X_2AVWIkZtqjNRPPBVivk0RjsR2jSjoq, 2015-11-2.

[22] Baidu library, "On the theory of female writing and Chinese Context," http://wenku.baidu.com/link?url=G7LZDAQuKzGb_ZhvfCJMvBX2lpedBjIkJO9uMIiMCTOF 5XIBqoZq_zBda2TE6P2D21guewiqv58uygNfJTKztcR1R2wH8cJinKUXrZ6-XLi, 2015-11-2.

[3] Z. Y. Zhang, J. Wang, "Showalter and Western Feminist Literary Criticism," Journal of Kaifeng Institute of Education, vol. 34, no. 3, pp. 11-12, 2014.

[4] darling's blog, "Overview of feminist literary criticism," http://blog.sina.com.cn/s/blog_4d3e73150100j3uh.html, 2015-11-1.

[5] Y. Gao, "Field generation and multivariate construction on feminist literary criticism," Seeker, vol. 35, no. 5, pp. 135-139, 2015.

[6] W. X. Sun, "The problem consciousness of the literary criticism of Marx," Journal of South China Normal University (Social Science Edition), vol. 59, no. 4, pp. 35-38, 2014.

[7] H. Y. Liu, "Comparison of Freud and Carl Jung's spirit of literary criticism," Hubei Social Sciences, vol. 28, no. 8, pp. 144-147, 2014.

[8] S. N. Xu, "Aitmatov's creation from the perspective of eco feminist literary criticism," Master's degree of Northeast Normal University, 2014. 
[9] LUO Xiao-rong, "On post modernist feminist literary criticism in the predicament," Journal of Taiyuan Normal University (Social Science Edition), vol. 8, no. 5, pp. 95-97, 2009.

[10] XIAO Lihua, "Gender Narration and Nationalism: Nation - state in Postcolonial - feminist Literary Criticism," Journal of Wenzhou University (Social Sciences), vol. 26, no. 6, pp. 30-35, 2013.

[11] Helena Forsås-Scott, "From concept of woman studies to gendered texts: Feminist literary criticism in Sweden," Women's Studies International Forum, vol. 18, no. 2, pp. 223-233, 2015. 